\title{
PENERBITAN KARTU NIKAH DI ERA DIGITAL PERSPEKTIF MASLAHAH
}

\author{
Zakiyatul Ulya* \\ Universitas Islam Negeri (UIN) Sunan Ampel Surabaya \\ E-mail: ulyaelzakiya@gmail.com
}

\begin{abstract}
Giving a marriage card together with marriage book for a married couple after the marriage contract is completed, as a consequence of the issuance of Peraturan Menteri Agama Nomor 19 Tahun 2018 tentang Pencatatan Perkawinan, has caused polemics among the public, especially regarding the urgency of issuing the card. In this case, some cicles consider that the issuance of marriage cards has a positive impact in facing demands in the digital era, especially in terms of efficiency, originality and data integration; on the contrary some other circles stated that the issuance of marriage card was not necessary given the existence of a marriage book so that it could potentially waste the budget, but this opinion was countered. If viewed from the aspect of its existence, the issuance of marriage cards includes maslahah mursalah because it is not all supported or rejected by the dalil syara', but in line with syara law; in terms of the level of their needs, including maslahah hajiyah because it complements the existence of a marriage book so that it makes it easier to live life and eliminate the difficulties associated with hifdh al-nasl; in terms of its content, including maslahah 'ammah because it relates to interests of the majority of Indonesian citezens; in terms of its content, including maslahah mah ammah because it relates to the interests of the majority of Indonesian citizens; and in terms of changes, including maslahah mutaghayirah because it allows for changes in human human needs related to proof of marital status in line with the changing era.
\end{abstract}

Keywords: Marriage card, digital era, maslahah

\begin{abstract}
Abstrak
Pemberian kartu nikah di samping buku nikah untuk pasangan suami istri setelah proses akad nikah selesai dilaksanakan, sebagai konsekuensi atas terbitnya Peraturan Menteri Agama Nomor 19 Tahun 2018 tentang Pencatatan Perkawinan, telah menimbulkan polemik di kalangan masyarakat, terutama mengenai urgensi diterbitkannya kartu tersebut. Dalam hal ini, beberapa kalangan menilai bahwa penerbitan kartu nikah berdampak positif dalam menghadapi tuntutan di era digital terutama dari segi efisiensi, orisinalitas dan integrasi data; dan beberapa kalangan yang lain menyatakan bahwa penerbitan kartu nikah tidak diperlukan mengingat telah adanya buku nikah sehingga berpotensi memboroskan anggaran, namun pendapat ini telah dimentahkan adanya. Jika dilihat dari segi eksistensinya, penerbitan kartu nikah termasuk maslahah mursalah karena sama sekali tidak didukung atau ditolak oleh dalil syara', tetapi sejalan dengan hukum syara'; dari segi tingkat kebutuhannya, termasuk maslahah hajiyah karena melengkapi keberadaan buku nikah dan memudahkan dalam menjalani kehidupan dan menghilangkan kesulitan yang berkaitan dengan hifdh al-nasl; dari segi kandungannya, termasuk maslahah 'ammah karena berkaitan dengan kepentingan mayoritas warga Indonesia; dari segi perubahannya, dan termasuk maslahah mutaghayirah karena memungkinkan adanya perubahan kebutuhan manusia terkait dengan pembuktian status perkawinan sejalan dengan perubahan era.
\end{abstract}

Kata Kunci: Kartu nikah, Era Digital, Maslahah

* Dosen HKI Fakultas Syariah dan Hukum Universitas Negeri Sunan Ampel Surabaya. 
ADHKI: Journal of Islamic Family Law

\section{Pendahuluan}

Pernikahan atau yang sekarang lebih poluler dengan istilah perkawinan adalah perbuatan yang sakral dan merupakan sunnatullah yang berlaku umum bagi makhluk-Nya, baik manusia, hewan maupun tumbuh-tumbuhan serta dipilih oleh-Nya sebagai cara makhluk-Nya untuk berkembang biak dan melestarikan keturunan. Tentunya ketentuan perkawinan yang berlaku bagi manusia berbeda dengan makhluk-Nya yang lain karena manusia merupakan makluk yang mulia, berbeda dengan makhluk lainnya salah satunya karena dibekali akal untuk berfikir (hayawanun natiq) Ulama berbeda pendapat dalam banyak hal mengenai perkawinan termasuk mengenai pengertiannya yang tentunya akan berimplikasi lebih jauh terhadap persoalan lainnya.

Ulama Syafi'iyah mendefinisikan perkawinan sebagai akad/perjanjian yang bermaksud untuk membolehkan adanya hubungan kelamin dengan lafadh nakaha atau zawaja. Definisi yang serupa dinyatakan oleh ulama Hanafiyyah yang menyatakan bahwa perkawinan merupakan akad yang ditentukan untuk memberi hak kepada laki-laki menikmati kesenangan dengan perempuan secara sengaja. Kedua definisi tersebut dan definisi-definisi lain yang diberikan ulama terdahulu pada kitab klasiknya begitu sederhana yang hanya mengemukakan tentang hakikat perkawinan berupa kebolehan untuk melakukan hubungan kelamin pasca akad perkawinan dilaksanakan. Pengertian perkawinan kemudian diperluas jangkauannya oleh ulama kontemporer yang salah satunya adalah Dr. Ahmad Ghandur yang dalam bukunya al-Ahwal al-Syakhsiyah di al-Tashri; al-Islamiy menyebutkan bahwa perkawinan adalah:

"Akad yang menimbulkan kebolehan untuk bergaul antara laki-laki dan perempuan sebagai tuntutan naluri kemanusiaan dalam kehidupannya dan menjadikan untuk keduanya beberapa hak dan kewajiban secara timbal balik." 1

Dari definisi di atas, diketahui bahwa adanya perkawinan akan menimbulkan berbagai dampak setelah pelaksanaannya, baik yang berhubungan dengan kedua pengantin atau orang lain yang berkaitan dengan keduanya. Oleh karena itu, meskipun perkawinan merupakan perbutan privat, namun karena besarnya dampak yang akan ditimbulkan ke depannya, maka di samping agama masing-masing, Negara juga turut serta mengatur peristiwa tersebut dengan cukup detail dalam beberapa perundang-undangannya, yang aturan tersebut antara lain tertuang dalam Undang-undang Nomor 1 Tahun 1974 tentang Perkawinan dan aturan pelaksanaannya, Kompilasi Hukum Islam, Peraturan Menteri Agama Nomor 11 Tahun 2007 jo Peraturan Menteri Agama Nomor 19 Tahun 2018 tentang Pencatatan Perkawinan.

Adanya aturan-aturan di atas, terutama Kompilasi Hukum Islam antara lain juga untuk memberikan kepastian hukum bagi warga negara serta

1 Amir Syarifuddin, Hukum Perkawinan Islam di Indonesia; Antara Figh Munakahat dan Undang-undang Perkawinan (Jakarta: Kencana, 2009), 37-39. 
mengatasi adanya perbedaan yang terjadi di kalangan ulama. Dalam pasal 1 Undang-undang Nomor 1 Tahun 1974 tentang Perkawinan menyatakan bahwa "perkawinan merupakan ikatan lahir batin antara seorang pria dan wanita sebagai suami istri dengan tujuan membentuk keluarga/rumah tangga bahagia dan kekal berdasarkan Ketuhanan YME" ${ }^{2}$ Hal ini senada juga dengan pasal 2 dan 3 Kompilasi Hukum Islam, yang menyatakan perkawinan/pernikahan sebagai "akad yang kuat/mitssaqan ghalidzan demi mentaati perintah Allah dan melaksanakannya merupakan ibadah serta bertujuan untuk mewujudkan kehidupan rumah tangga yang sakinah, mawaddah dan rahmah". ${ }^{3}$

Keabsahan sebuah perkawinan tergantung pada agama dan kepercayaannya masing-masing, dalam arti perkawinan harus dilakukan sesuai dengan hukum agama dan kepercayaan tersebut. ${ }^{4}$ Perkawinan baru dinyatakan sah jika terpenuhi rukun dan syaratnya serta terbebas dari larangan perkawinan. Rukun tersebut dinyatakan dalam pasal 14 Kompilasi Hukum Islam, bahwa dalam melaksanakan sebuah perkawinan harus ada calon pengantin suami dan istri, wali nikah, dua orang saksi, ijab dan kobul. Kelima rukun tersebut memiliki syarat masing-masing yang dirinci secara jelas dalam pasal 15 sampai dengan 29 Kompilasi Hukum Islam. Adapun mengenai larangan perkawinan tertuang dalam pasal 39 sampai 44 Kompilasi Hukum Islam. ${ }^{5}$ Ketentuan-ketentuan tersebut terus dilengkapi dan dirinci, bahkan dilakukan beberapa pembaharuan dalam peraturan-peraturan yang dikeluarkan setelahnya.

Untuk mempunyai kekuatan hukum, sebuah perkawinan harus dicatatankan menurut perundang-undangan yang berlaku. Pencatatan tersebut harus dilakukan oleh Pegawai Pencatat Nikah (PPN) sesuai dengan ketentuan Undang-undang Nomor 22 Tahun 1946 jo Undang-undang Nomor 32 Tahun 1954 tentang Pencatatan Nikah, Talak dan Rujuk. Dengan demikian, setiap perkawinan harus dilaksanakan dihadapan dan di bawah pengawasan Pegawai Pencatat Nikah karena sebuah perkawinan hanya dapat dibuktikan dengan akta yang dibuat oleh Pegawai Pencatat Nikah tersebut. ${ }^{6}$

Dalam pasal 27 Peraturan Menteri Agama Nomor 11 Tahun 2011 tentang Pencatatan Perkawinan disebutkan bahwa setelah proses akad selesai dilakukan, pasangan suami istri akan diberikan buku nikah yang merupakan kutipan akta nikah sebagai bukti pernikahan tersebut telah sah secara agama dan diakui oleh Negara. ${ }^{7}$ Adapun dengan diterbitkannya peraturan terbaru mengenai pencatatan perkawinan, yaitu Peraturan Menteri Agama Nomor 18 Tahun 2019, pasangan suami istri yang melaksanakan pernikahan secara resmi, dalam arti dicatatkan di Kantor Urusan Agama tidak hanya akan memperoleh Buku

2 Pasal 1 Undang-undang Nomor 1 Tahun 1974 tentang Perkawinan.

3 Pasal 1 dan 2 Kompilasi Hukum Islam.

4 Pasal 2 ayat (1) Undang-undang Nomor 1 Tahun 1974 tentang Perkawinan.

5 Pasal 14-29, 39-44 Kompilasi Hukum Islam.

6 Pasal 5-7 Kompilasi Hukum Islam.

7 Pasal 27 Peraturan Menteri Agama Nomor 11 Tahun 2007 tentang Pencatatan Perkawinan. 
Pencatatan Perkawinan tetapi juga Kartu Perkawinan. ${ }^{8}$

Adapun kartu nikah ini mulai dicetak dan didistribusikan pada November 2018 sebagai inovasi dari Direktorat Jenderal Bimbingan Masyarakat Islam Kementerian Agama yang sejalan dengan adanya peluncuran Sistem Informasi dan Manajemen Nikah Berbasis Website (SIMKAH Web) yang merupakan pengembangan dari aplikasi SIMKAH generasi pertama yang berbasis Desktop yang dirancang guna memudahkan pengelolaan administrai nikah dan rujuk dengan dukungan validitas data yang terintegrasi dengan data Kependudukan dan Catatan Sipil. Menurut Muhammadiyah Amin, Direktur Jenderal Bimas Islam menyatakan bahwa penerbitan kartu nikah diantaranya dilatarbelakangi karena berlakunya era digital serta demi meminimalisir maraknya pemalsuan buku nikah yang terjadi akhir-akhir ini. ${ }^{9}$

Penerbitan kartu nikah ini dilakukan secara bertahap. Tahap awal hanya bisa dilakukan oleh Kantor Urusan Agama di daerah yang mempunyai koneksi internet yang baik. Akan tetapi menurut Mohsen, Direktur Bina Kantor Urusan Agama Kementerian Agama menyatakan bahwa penyebaran kartu nikah secara merata ke 34 Provinsi di Indonesia ditargetkan telah selesai direalisasikan pada tahun 2019 ini. ${ }^{10}$ Proyek percontohan pelayanan kartu nikah pada tahap awal ini di mulai di 67 kabupaten dan kota dan selanjutnya akan terus dikembangkan sesuai dengan kesiapan sistem yang ada serta sarana dan prasarana yang dimiliki oleh Kantor Urusan Agama. Oleh karena itu, penyiapan infrastruktur berupa server dan jaringan yang memadai untuk mengoprasikan aplikasi SIMKAH Web serta penggunaan kartu nikah secara nasional terus juga terus dilakukan secara bertahap. ${ }^{11}$

Rencana penerbitan kartu nikah memunculkan kerisauan di kalangan masyarakat, bahkan menjadi viral di media sosial. Dalam hal ini, masyarakat mengira bahwa penerbitan kartu nikah adalah untuk menghapus keberadaan buku nikah yang selama ini menjadi bukti sah terjadinya sebuah perkawinan. Akan tetapi, perkiraan tersebut dimentahkan dengan adanya penegasan dari Menteri Agama, Lukman Hakim Saifuddin terkait penerbitan kartu nikah oleh Kementerian agama bukan untuk menghapus atau mengganti buku nikah yang merupakan dokumen resmi, namun sebagai tambahan informasi untuk memudahkan setiap warga masyarakat yang memerlukan data kependudukan dan status perkawinannya karena terintegrasi langsung dengan data

\footnotetext{
8 Pasal 18 ayat (1) Peraturan Menteri Agama Nomor 19 Tahun 2018 tentang Pencatatan Perkawinan.

9 Republika.co.id, "Penjelasan Kemenag Soal Penerbitan Kartu Nikah", dalam https://www.republika.co.id/berita/dunia-islam/islam-nusantara/18/11/12/pi1dgz313-penjelasan-ke menag-soal-penerbitan-kartu-nikah, diakses pada 26 Juni 2019.

10 Harian Nasional, "Penerbitan Kartu Nikah Bertahap", dalam http://www.harnas.co/2018/11/12/penerbitan-kartu-nikah-bertahap, diakses pada 27 Juni 2019.

11 Republika.co.id, "Kartu Nikah, Disorot tapi Dinanti", https://www.republika.co.id/berita/dunia-islam/islam-nusantara/18/12/31/pk799p384-kartu-nikah-d isorot-tapi-dinanti, diakses pada 27 Juni 2019.
} 
kependudukan dan catatan sipil di bawah Kementerian Dalam Negeri sebagaimana yang telah disebutkan sebelumnya. ${ }^{12}$ Meskipun begitu, menurut Muhammadiyah Amin tetap direncanakan pada 2020 buku nikah sudah tidak digunakan lagi dan perannya benar-benar digantikan oleh kartu nikah. ${ }^{13}$

Selain viralnya kerisauan masyarakat di media sosial, rencana penerbitan kartu nikah ini juga menuai pro kontra di beberapa kalangan. Kalangan yang pro menyatakan bahwa kartu nikah memiliki beberapa kelebihan antara lain lebih efisien, akurat dan terintegrasi, tidak mudah dipalsukan, mudah dibawa kemana-mana sehingga sangat bermanfaat ketika tiba-tiba dibutuhkan. Berbeda dengan itu, beberapa kalangan lain menyatakan bahwa penerbitan kartu nikah tidak tepat dan cenderung berpotensi terhadap pemborosan anggaran karena masyarakat telah banyak memiliki kartu, antara lain Kartu Indonesia Sehat (KIS), Kartu Indonesia Pintar (KIP), dan bahkan Kartu Tanda Penduduk (KTP) yang sudah memuat data kependukan sekaligus status perkawinan. ${ }^{14}$

Perdebatan mengenai penerbitan kartu nikah terus bergulir bahkan ketika kartu nikah tersebut telah diujicobakan di beberapa daerah di Indonesia. Hal ini tidak terlepas dari adanya fakta di lapangan yang memperlihatkan kekurangsiapan terkait sarana dan prasarana maupun SDM (Sumber Daya Manusia) yang dibutuhkan dalam pelaksanaan nya. Meskipun begitu, dalam faktanya tanggapan positif juga muncul dari beberapa kalangan di daerah yang telah melakukan ujicoba terkait dengan kemanfaatan yang didapatkan dengan adanya penerbitan kartu nikah, tentunya dengan beberapa perbaikan yang harus dilakukan, terutama mengenai sarana dan prasarana serta Sumber Daya Manusia sebagaimana yang telah disebutkan.

Dari fakta di atas, perlu adanya analisis yang baru terkait penerbitan kartu nikah dengan perspektif maslahah untuk mengetahui perlu tidaknya penerbitan kartu nikah ini dilanjutkan dan diterapkan di seluruh Indonesia dengan melihat segi kemanfaatan dan kemadharatan yang didapatkan. Penelitian ini menjadi penting karena pertama kali dilakukan, dalam arti belum ada yang melakukan penelitian ini sebelumnya dan hasilnya dapat dijadikan bahan masukan untuk pihak yang berwenang, salah satunya adalah Kementerian Agama, dalam penyelenggaraan penerbitan kartu nikah ke depannya.

\section{Konsep Maslahah dalam Hukum Islam}

12 Kontan.co.id, "Menag: Kartu Nikah Bukan Penghapus Buku Nikah", dalam https://nasional.kontan.co.id/news/menag-kartu-nikah-bukan-penghapus-buku-nikah, diakses pada 28 Juni 2019.

13 Convensianews, "Kemenag Bakal Terbitkatkan Kartu Nikah, Begini Penampakannya", dalam

https://covesia.com/news/baca/63643/kemenag-bakal-terbitkan-kartu-nikah-begini-penampakannya, diakses pada 29 Juni 2019.

14 Faktualnews.co., "Pro Kontra Penerbitan Kartu Nikah", dalam https://faktualnews.co/2018/11/13/pro-kontra-penerbitan-kartu-nikah/107958/, diakses pada 28 Juni 2019. 
Fondasi bangunan Syariah Islam dipesentrasikan oleh maslahah yang ditujukan untuk kepentingan manusia sebagai hamba Allah Swt., baik yang menyangkut kehidupan dunawi maupun ukhrawi. Syariat Islam sendiri sangat menjunjung tinggi prinsip keadilan (adalah), kasih sayang (rahmah), dan maslahah, sehingga segala aturan hukum yang bertentangan dengan prinsip-prinsip tersebut hakikatnya bukanlah bagian dari syariah Islam. Keluhuran syariah Islam termanifestasikan pada kompabilitas hukum-hukum syariah atas perkembangan manusia lantaran digerakan oleh ruh maslahah. ${ }^{15}$

Secara terminologis, maslahah telah diberi muatan makna oleh beberapa ahli usul fikih, yang antara lain:

1. Al-Ghazali mendefiniskan maslahah sebagai sesuatu yang mewujudkan kemanfaatan dan menghindarkan kemadharatan (jalb al-manfa'ah dan daf' al-madharrah). Maslahah diartikan sebagai perwujuadan tujuan syara' yang berupa pemeliharaan agama, jiwa, akal, keturunan dan harta. Oleh karena itu, segala sesuatu yang dapat menjamin eksistensi kelima hal tersebut dikatagorikan sebagai maslahah, begitu juga sebaliknya segala sesuatu yang dapat merusak kelimanya dikatagorikan sebagai mafsahad, sehingga mencegahnya termasuk ke dalam maslahah. ${ }^{16}$

2. Al-Thufi mendefinisikan maslahah dari dua segi, yaitu dari segi 'urf sebagai sebab yang akan membawa kepada keuntungan dan dari segi syara' sebagai sebab yang akan membawa kepada tujuan Shari', baik yang berkenaan dengan persoalan ibadan maupun muamalah. Dengan demikian, kemaslahatan yang dimaksud oleh Al-Tufi adalah yang sejalan dengan tujuan syara' bukan didasarkan pada akal semata sebagaimana yang tercantum dalam al-Daruriyah al-Khamsah, yaitu hifdh al-din, al-'aql, hifdh, hifdh al-nafs, hifdh al-nasl, dan hifdh al-mal (pemeliharaan agama, akal, jiwa, keturunan dan harta). ${ }^{17}$

3. Al-Syatibi mengartikan maslahah dari dua segi, yaitu dari segi terjadinya maslahah dalam kenyataan sebagai sesuatu yang kembali kepada sempurnanya kehidupan manusia dengan tercapainya semua yang diinginkan sesaui dengan syahwat dan akalnya, dan dari segi tergantungnya tuntutan syariat kepada maslahah sebagai tujuan adanya penetapan hukum. Adapun untuk menghasilkan kemaslahatan, Allah menuntuk kepada manusia untuk melakukan sesuatu sehingga aturannya tetap berjalan dengan semestinya.

4. Izz al-Din mendefinisikan maslahah ke dalam dua makna, yaitu dalam bentuk hakiki sebagai kesenangan dan kenikmatan serta dalam bentuk

15 Muhammad Harfin Zuhdi, “Formulasi Teori Maslahah dalam Paradigma Pemikiran Hukum Islam Kontemporer", dalam Istinbat, Vol. 12, No. 1 (Desember, 2013), 293.

16 Asmawi, "Konseptualisasi Teori Maslahah, dalam Salam: Jurnal Filsafat dan Budaya Hukum (2014), 314.

17 Qusthoniah, "Al-Mashlahah dalam Pandangan Najmuddun al-Thufi", dalam Jurnal Syar'ah, Vol. II, No. II (Oktober, 2013), 41-42. 
majazi sebagai sebab yang akan mendatangkan kesenangan dan kenikmatan. Pemaknaan ini berdasarkan adanya pandangan dasar bahwa prinsipnya manfaat memiliki empat bentuk, yaitu kenikmatan dan sebab-sebabnya serta kesenangan dan sebab-sebabnya.

Dari beberapa definisi di atas, dapat disimpulkan bahwa pada dasarnya maslahah adalah sesuatu yang dianggap baik oleh akal karena mewujudkan kebaikan/kemafaatan dan menghindarkan bahaya/kerusakan bagi manusia serta sejalan dengan tujuan syara', yang berkenaan dengan pemeliharaan lima prinsip pokok dalam kehidupan manusia (agama, jiwa, akal, keturunan dan harta). ${ }^{18}$ Dengan demikian, yang disebut suatu kemaslahatan tidak cukup dianggap baik oleh akal tetapi juga harus sesuai dengan syara'. Selanjutnya, Yusuf Hamid menjelaskan mengenai keistimewaan maslahah syariat dibanding dengan maslahah secara umum yaitu:

1. Standar ukurannya adalah petunjuk syariat bukan hanya akal manusia yang tidak sempurna, dibatasi tempat dan waktu, bersifat subjektif dan relatif serta terpengaruh hawa nafsu dan lingkungan.

2. Pembatasan maslahah dan mafsadah tidak terbatas pada kepentingan duniawi saja tetapi juga ukhrawi, tidak hanya kepentingan sesaat tetapi sepanjang masa.

3. Tidak terbatas pada rasa enak dan tidak enak dalam konteks fisik/jasmani saja tetapi juga dalam konteks mental/spiritual.

4. Asas/inti dari kemaslahatan lainnya. ${ }^{19}$

Ulama berbeda pendapat kehujjahan maslahah sebagai dalil dalam menetapkan hukum. Golongan pertama menyatakan bahwa penggunaan maslahah sebagai landasan/dalil hukum dalam berijtihad diperbolehkan, sedangkan golongan kedua mengatakan bahwa penggunaan maslahah dalam pelaksanaan ijtihad tidak diperbolehkan. Adanya perbedaan ini tidak lain karena tidak adanya dalil khusus, baik secara langsung maupun tidak langsung mengenai diterimanya maslahah sebagai dalil hukum. Akan tetapi, melihat banyaknya persoalan baru yang muncul dan tidak adanya dalil, baik dalam al-qur'an maupun hadis yang menjelaskan hukumnya, maka konsep maslahah ini dipandang relevan untuk menyelesaikannya agar Islam mudah dipahami dan diamalkan serta tidak menyulitkan karena Islam adalah rahmatan lil 'alamin. ${ }^{20}$

Dalam hal ini, kalangan Malikiyah dan Hanabilah menentukan beberapa syarat agar suatu maslahah dapat dijadikan hujjah dengan rincian sebagai berikut:

1. Sejalan dengan kehendak syara' dan didukung nash secara umum.

2. Bersifat rasional dan pasti bukan merupakan perkiraan dalam mewujudkan

\footnotetext{
18 Muhammad Ali Rusdi, "Maslahat sebagai Metode Ijtihad dan Tujuan Utama Hukum Islam”, dalam Jurnal Syari'ah dan Hukum Diktum, Vol. 15, No. 2 (Desember, 2017), 152-153.

19 Ibid., 155.

${ }^{20}$ Hamzah K, "Urgensi Maslahah dalam Pembaharuan Hukum Islam di Era Global", dalam Al-Manahij: Jurnal Kajian Hukum Islam, Vol. 8, No. 2 (2014).
} 
kemanfaatan dan menghindarkan kemadharatan.

3. Berlaku umum, dalam arti menyangkut kepentingan orang banyak bukan pribadi. ${ }^{21}$

Pembagian maslahah dapat dilihat dari beberapa segi berikut:

1. Dari segi eksistensi/keberadaannya, maslahah terbagi menjadi tiga, yaitu:

a. Maslahah mu'tabarah (kemaslahatan yang diakui oleh dalil syara').

b. Maslahah mursalah (kemaslahatan yang tidak didukung oleh dalil syara' dan tidak pula ditolak olehnya, tetapi sejalan dengan hukum syara').

c. Maslahah mulghah (kemaslahatan yang bertentangan dengan dalil syara').22

2. Dari segi tingkat kebutuhannya, maslahah dibagi menjadi tiga, yaitu:

a. Maslahah daruriyah (kemaslahatan yang keberadaannya sangat dibutuhkan oleh kehidupan manusia karena berhubungan dengan kebutuhan pokok umat manusia, berupa pemeliharaan lima prinsip pokok (hifdh al-din, al-'aql, hifdh, hifdh al-nafs, hifdh al-nasl, dan hifdh al-mal) dalam kehidupan manusia, sehingga jika tidak dipenuhi maka akan menyebabkan kerusakan. ${ }^{23}$

b. Maslahah hajiyah (kemaslahatan yang menyempurnakan kemaslahatan sebelumnya dengan bentuk keringanan dalam mempertahankan dan memelihara lima prinsip pokok dalam kehidupan manusia). ${ }^{24}$

c. Maslahah tahsiniyah (kemaslahatan yang perlu dipenuhi dalam rangka memberikan keindahan bagi kehidupan manusia, yang juga berkaitan dengan lima prinsip pokok dalam kehidupan manusia). ${ }^{25}$

3. Dari segi kandungannya, maslahah terbagi menjadi dua, yaitu:

a. Maslahah 'ammah (kemaslahatan umum yang berkaitan dengan kepentingan orang banyak, dalam arti tidak harus kepentingan semua orang tetapi bisa dengan kepentingan mayoritas orang).

b. Maslahah khassah (kemaslahatan yang berkaitan dengan kepentingan pribadi dan sangat jarang terjadi).

4. Dari segi perubahannya, maslahah dibagi menjadi dua, yaitu:

a. Maslahah thabitah (kemaslahatan yang tetap dan tidak berubah sampai akhir zaman).

b. Maslahah mutaghayirah (kemaslahatan yang berubah-ubah sesuai dengan tempat dan waktu). ${ }^{26}$

\footnotetext{
${ }^{21}$ Muksana Pasaribu, "Maslahat dan Perkembangannya sebagai Dasar Penetapan Hukum Islam", dalam Jurnal Justitia, Vol. 1, No. 4 (Desember, 2014), 357.

${ }^{22}$ Hamzah K, “Urgensi Maslahah dalam Pembaharuan Hukum Islam di Era Global”.

23 Amir Syarifuddi, Ushul Figh (Jakarta: Kencana, 2011), 349.

${ }^{24}$ Muksana Pasaribu, "Maslahat dan Perkembangannya sebagai Dasar Penetapan Hukum Islam"..., 354

25 Amir Syarifuddi, Ushul Figh..., 350.

${ }_{26}$ Muksana Pasaribu, "Maslahat dan Perkembangannya sebagai Dasar Penetapan Hukum Islam"..., 355.
} 


\section{Rukun dan Syarat Perkawinan dalam Peraturan Menteri Agama Nomor 19 Tahun 2019 tentang Pencatatan Perkawinan}

Persoalan rukun dan syarat sebenarnya telah diatur dalam berbagai peraturan mengenai perkawinan dan pencatatannya yang ada sebelum terbitnya Peraturan Menteri Agama Nomor 19 Tahun 2018 tentang Pencatatan Perkawinan. Hanya saja dalam hal ini hanya akan dibahas rukun dan syarat dalam Peraturan Menteri Agama Nomor 19 Tahun 2018, guna menghubungkannya dengan ketentuan mengenai kartu nikah dalam peraturan ini. Adapun rukun perkawinan yang diatur dalam pasal 9 Peraturan Menteri Agama Nomor 19 Tahun 2018 tentang Pencatatan Perkawinan terdiri dari: calon suami, calon istri, dua orang saksi, serta ijab dan kabul, ${ }^{27}$ dengan beberapa persyaratan berikut:

1. Calon suami dan istri menghadiri akad, atau jika calon suami tidak hadir dapat diwakilkan kepada orang lain dengan adanya surat kuasa yang diketahui oleh pejabat yang berwenang. Adapun syarat wakil adalah laki-laki, Islam, usia minimal 21 tahun, berakal dan baligh.

2. Wali terdiri dari wali nasab yang syaratnya meliputi laki-laki, Islam, baligh, berakal dan adil serta wali hakim. Wali nasab memiliki urutan sebagaimana yang disebutkan dalam pasal 11 ayat (3) Peraturan Menteri Agama Nomor 19 Tahun 2018 tentang Pencatatan Perkawinan. Wali tersebut boleh mewakilkan kepada pihak yang memenuhi syarat dan harus dilengkapi dengan surat taukil wali jika tanpa kehadiran wali yang mewakilkan. Adapun wali hakim dijabat oleh kepala KUA Kecamatan yang dapat bertindak sebagai wali hanya jika walinya tidak ada, adhal (ditetapkan oleh pengadilan), tidak diketahui keberadaannya (berdasarkan surat pernyataan calon pengantin dengan diketahui lurah/kepala desa setempat), dalam masa tahanan sehingga tidak dapat dihadirkan (dibuktikan dengan surat keterangan dari instansi berwenang) atau non muslim. ${ }^{28}$

3. Dua orang saksi disyaratkan laki-laki, Islam, baligh, berakal dan adil sebagaimana syarat pada wali nasab.

4. Ijab dalam perkawinan dilakukan oleh wali sedangkan kabul dilakukan oleh calon suami atau wakilnya. ${ }^{29}$

\section{Sistem Informasi Manjeman Nikah Berbasis Web (SIMKAH Web)}

Sebagaimana yang telah dipaparkan sebelumnya bahwa Sistem Informasi dan Manajemen Nikah Berbasis Website (SIMKAH Web) merupakan pengembangan dari aplikasi SIMKAH berbasis Desktop. Aplikasi ini dirancang guna memudahkan pengelolaan administrai nikah dan rujuk pada KUA dengan dukungan validitas data yang terintegrasi dengan data Kependudukan dan

\footnotetext{
27 Pasal 9 Peraturan Menteri Agama Nomor 19 Tahun 2018 tentang Pencatatan Perkawinan.

28 Pasal 10-12 Peraturan Menteri Agama Nomor 19 Tahun 2018 tentang Pencatatan Perkawinan.

29 Pasal 13-14 Peraturan Menteri Agama Nomor 19 Tahun 2018 tentang Pencatatan Perkawinan.
} 
Catatan Sipil yang ada di bawah Dukcapil Kementerian Dalam Negeri. ${ }^{30}$ Peluncuran aplikasi ini juga merupakan tindak lanjut dari adanya Nota Kesepahaman antara Menteri agama dengan Menteri Dalanm Negeri Nomor: 470/5711/SJ dan Nomor 20 Tahun 2015 tentang Kerjasama Pemanfaatan Nomor Induk Kependudukan, Data Kependudukan dan KTP Elektronik dalam Lingkuo Kementerian Agama. ${ }^{31}$ Adapun sejumlah keuntungan dalam penggunaan aplikasi ini, yaitu:

1. Aplikasi SIMKAH Web dapat diunduh secara langsung oleh semua kalangan masyarakat melalui www.simkah.kemenag.go.id. atau http://simkah.kemenag.go.id. ${ }^{32}$

2. Mudah digunakan karena input datanya cukup dengan menggunakan Nomor Induk Kependudukan (NIK) yang secara otomatis formulir nikahnya telah terisi dengan data yang dibutuhkan untuk membuat akta nikah dan kutipannya (buku nikah) serta kartu nikah. ${ }^{33}$

3. Dilengkapi fitur survey kepuasan masyarakat, sehingga di web ini masyarakat juga dapat memberikan saran dan masukan terhadap pelayanan yang dilakukan oleh pegawai KUA sehingga dapat dijadikan bahan perbaikan ke depannya.

4. Tersedia menu layanan publik untuk mendaftar nikah yang dapat diakses secara online, sehingga masyarakat akan mengetahui secara langsung terkait berapa biaya nikah dan kemana harus disetorkan, jadwal yang tersedia untuk melangsungkan perkawinan dan sebagainya. Selanjutnya mereka yang telah mendaftar melalui SIMKAH Web juga akan memperoleh kartu nikah. ${ }^{34}$

5. Terintegrasi/terkoneksi dengan Sistem Informasi Akademik (SIAK) Kementerian Dalam Negeri dan Sistem Informasi Penerimaan Negara Bukan Pajak Online (SIMPONI).

6. Bebagai informasi terkait pendaftaran maupun pencatatan nikah tersaji dalam bentuk tabel, grafik maupun statistik secara real time..$^{35}$

7. Buku nikah dan kartu nikah yang akan diberikan kepada pasangan suami

${ }^{30}$ Republika.co.id, "Penjelasan Kemenag Soal Penerbitan Kartu Nikah".

31 Republika.co.id, "Mengapa Buku Nikah Diganti Kartu", dalam https://www.republika.co.id/berita/nasional/news-analysis/18/11/12/pi1gl3409-mengapa-buku-nika h-diganti-kartu, diakses pada 30 Juni 2019.

32 Tribunnews.com, "Mudahkan Pencatatan Nikah, Kemenag Luncurkan Aplikasi SIMKAH", dalam

http://www.tribunnews.com/nasional/2018/11/08/mudahkan-pencatatan-nikah-kemenag-luncurkan -aplikasi-simkah, diakses pada 30 Juni 2019.

${ }^{33}$ Kontan.co.id, "Ini Deretan Keunggulan Aplikasi SIMKAH Web yang dirilis Kemenag", dalam,https://nasional.kontan.co.id/news/ini-deretan-keunggulan-aplikasi-SIMKAH-web-yang-diri lis-kemnag diakses pada 30 Juni 2019.

34 Detiknews, "Kemenag Uji Coba Simkah Web di 2.000 KUA", dalam https://news.detik.com/berita/d-4303570/kemenag-uji-coba-simkah-web-di-2000-kua, diakses pada 30 Juni 2019.

35 Tribunnews.com, "Mudahkan Pencatatan Nikah, Kemenag Luncurkan Aplikasi SIMKAH”. 
istri dilengkapi dengan kode QR (Barcode) yang dapat dibaca dengan menggunakan Barcodel QR Scanner yang tersambung dengan aplikasi SIMKAH Web guna mengatasi maraknya pemalsuan buku nikah. ${ }^{36}$

\section{Penerbitan Kartu Nikah di Era Digital}

Dalam pasal 1 point 7 Peraturan Menteri Agama Nomor 19 Tahun 2018 tentang Pencatatan Perkawinan disebutkan bahwa kartu nikah/kartu perkawinan adalah buku pencatatan perkawinan/kutipan akta perkawinan (sebuah akta autentik pencatatan peristiwa perkawinan) dalam bentuk kartu elektronik ${ }^{37}$ dan diserahkan kepada pasangan suami istri bersamaan dengan buku nikah setelah proses akad selesai dilakukan. ${ }^{38}$ Sementara ini, Kementerian Agama memprioritaskan penerbitan kartu nikah untuk pasangan yang menikah pasca diluncurkannya kartu nikah, sedangkan bagi pasangan yang telah menikah sebelum peluncurannya akan mendapatkan kartu nikah secara bertahap dengan mekanisme pendistribusian yang masih akan diatur nantinya.

Kartu nikah diluncurkan secara resmi oleh Kementerian Agama sebagai pelengkap buku nikah pada tanggal 8 November 2019.39 Dengan demikian, kehadirannya tidak lantas menafikan buku nikah yang merupakan dokumen penting/resmi yang harus selalu dijaga oleh pasangan suami istri. Adapun kemunculan kartu nikah ini merupakan buah dari pengembangan aplikasi SIMKAH Web yang dapat mencetak buku nikah dan kartu nikah sekaligus. Kartu nikah berisi informasi mengenai rangkuman data sebagaimana yang terdapat dalam buku nikah, yaitu meliputi nama pasangan suami istri, nomor buku nikah, nomor KTP, tempat dan waktu pelaksanaan perkawinan.

Kartu nikah dapat memudahkan masyarakat untuk mengakses layanan Kantor Urusan Agama dimana pun berada yang telah terkoneksi dengan SIMKAH dan dapat meminimalisir adanya pemalsuan identitas perkawinan karena dilengkapi dengan kode QR (Barcode) yang terhubung secara langsung dengan aplikasi SIMKAH Web serta telah terintegrasi dengan Sistem Informasi Administrasi Kependudukan secara nasional. ${ }^{40}$ Kementerian Agama memiliki target terkait penggunaan kartu nikah yaitu agar pengelolaan administrasi nikah berbasis teknologi informasi dapat diterapkan di semua Kantor Urusan Agama di seluruh Indonesia sehingga kualitas pelayanan KUA dapat terus meningkat secara bertahap seiring dengan penggunaannya tersebut, sehingga tercipta modernisasi pengelolaan data kependudukan berbasis online secara real time,

\footnotetext{
36 Republika.co.id, "Mengapa Buku Nikah Diganti Kartu”.

37 Pasal 1 point 7 Peraturan Menteri Agama Nomor 19 Tahun 2018 tentang Pencatatan Perkawinan.

38 Pasal 18 ayat (1) dan (2) Peraturan Menteri Agama Nomor 19 Tahun 2018 tentang Pencatatan Perkawinan.

39 Kompas.com, "Kartu Nikah Diberikan Bersamaan dengan Buku Nikah, dalam "https://nasional.kompas.com/read/2018/11/12/21492291/kartu-nikah-diberikan-bersamaan-d engan-buku-nikah, diakses pada 29 Juni 2019.

40 Republika.co.id, "Kartu Nikah, Disorot tapi Dinanti".
} 
transparan, akuntabel dan mudah diakses oleh siapapun yang membutuhkannya. ${ }^{41}$

Kartu nikah yang dikeluarkan oleh Direktorat Jenderal Bimas Islam Kementerian Agama berbentuk persegi panjang berwarna dasar hijau dengan campuran kuning ${ }^{42}$ dengan banyak logo Kementerian Agama yang dibuat transparan. ${ }^{43}$ Adapun rincian bagiannya adalah:

1. Bagian depan terdiri dari:

a. Bagian atas yang berupa kop Kementerian Agama.

b. Bagian tengah terdapat tiga kotak, yaitu:

1) Dua kotak bagian atas berisikan foto pasangan suami istri dilengkapi dengan nama masing-masing di bawah foto tersebut.

2) Satu kotak bagian bawah berisi barcode/kode batang yang jika dipindai muncul data lengkap mengenai peristiwa nikah pemiliknya, yaitu berupa informasi rangkuman data digital sebagaimana yang terdapat pada buku nikah yang muatannya telah disebutkan di atas.

2. Bagian belakang terdapat terjemahan surat Ar-Rum ayat 21 dan di bagian bawahnya terdapat cap hologram Menteri Agama Republik Indonesia disertai dengan tahun pembuatan kartu tersebut. ${ }^{44}$

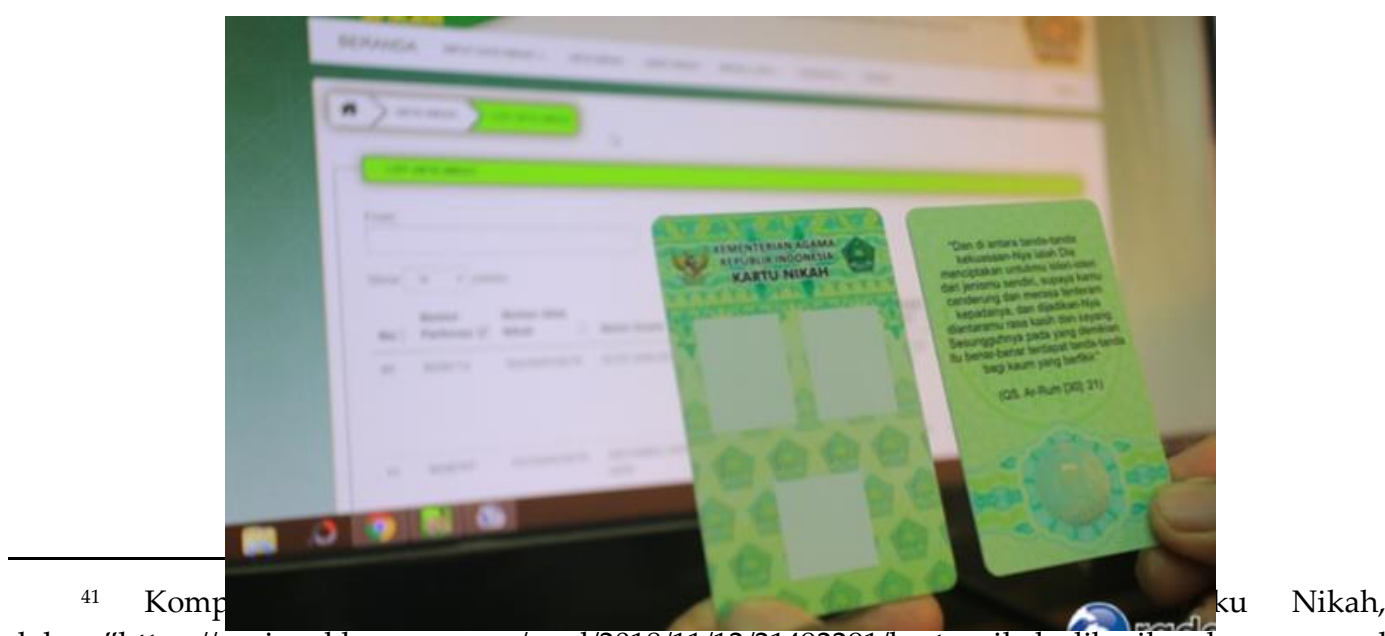

dalam "https://nasional.kompas.com/read/2018/11/12/21492291/kartu-nikah-diberikan-bersamaan-d engan-buku-nikah, diakses pada 29 Juni 2019.

42 Tribunjakarta.com, "7 Hal tentang Kartu Nikah Diterbitkan secara Bertahap, Ini Kelebihannya", dalam https://jakarta.tribunnews.com/2018/11/14/7-hal-tentang-kartu-nikah-diterbitkan-secara-bertahap-i ni-kelebihannya?page=3, diakses pada 29 Juni 2019.

43 Detiknews, "Begini Wujud Kartu Nikah Segera Gantikan Buku Nikah", dalam https://news.detik.com/berita/4296724/begini-wujud-kartu-nikah-yang-segera-gantikan-buku-nikah, diakses pada 28 Juni 2019. dalam

${ }^{44}$ Liputan6, "(Cek Fakta) Kementerian Agama Buat Kartu Nikah dengan 4 Kolom Istri", https://www.liputan6.com/cek-fakta/read/3695757/cek-fakta-kementerian-agama-buat-kartu-nikahdengan-4-kolom-istri, diakses pada 29 Juni 2019. 
Gambar 1.1.

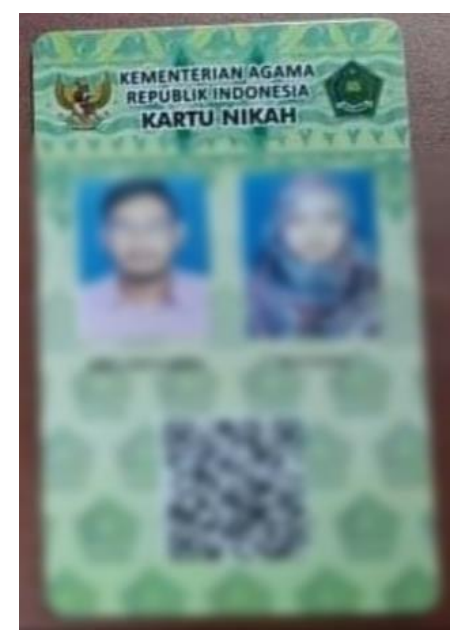

Gambar Kartu Nikah dan Tampilan SIMKAH Web

Sebagaimana yang telah disebutkan sebelumnya, bahwa penerbitan kartu nikah menuai pro kontra di berbagai kalangan masyarakat dengan berbagai argumennya masing-masing. Adapun rinciannya yaitu:

1. Kalangan yang mendukung tidak lain disebabkan beberapa kelebihan yang dimiliki oleh kartu nikah tersebut, antara lain:

a. Mudah dibawa kemanapun dan kapanpun

Dengan bentuknya yang kecil dan tipis seperti kartu ATM memudahkan untuk dibawa kemana-mana termasuk ketika bepergian bersama pasangan apalagi dengan menjamurnya hotel syariah yang mengharuskan untuk menunjukan bukti perkawinan pasangan yang akan menginap. Dalam hal ini, pasangan suami istri tidak perlu membawa buku nikah yang tebal lagi tetapi cukup dengan membawa kartu nikah yang bahkan dapat dimasukkan ke dalam dompet bersama kartu lainnya, karena di dalamnya telah tersimpan identitas pasangan suami istri sebagaimana yang ada di buku nikah.

b. Tersambung dengan aplikasi SIMKAH Web

Peluncuran kartu nikah bersamaan dengan peluncuran aplikasi Sistem Informasi Manajemen Nikah Berbasis Web (SIMKAH Web) yang memuat semua data berkenaan dengan pasangan pengantin dan terhubung dengan data Kependudukan dan Catatan Sipil (Dukcapil) yang dikelola oleh Kementerian dalam Negeri. Dengan demikian, jika perkawinan seseorang sudah tercatat pada aplikasi SIMKAH Web secara otomatis perkawinan tersebut juga telah terdata pada Dukcapil 
tanpa harus adanya pelaporan terlebih dulu. ${ }^{45}$

c. Memudahkan akses layanan Kantor Urusan Agama di seluruh Indonesia

Setiap pasangan suami istri dapat mengakses layanan KUA tidak hanya di tempat mereka menikah tetapi juga di daerah lain di seluruh Indonesia dengan catatan KUA tersebut telah terkoneksi dengan aplikasi SIMKAH Web.

d. Dapat digunakan sebagai data dukung yang akurat

Kartu nikah dapat dijadikan sebagai data pendukung yang akurat dalam memenuhi persyaratan yang mengharuskan adanya status perkawinan, misalnya dalam urusan perbankan, tanpa adanya pelampiran buku nikah atau legislasinya karena data yang terekam pada kartu ini dijamin keasliannya yang terintegrasi dengan Sistem Informasi Akademik (SIAK) Kementerian Dalam Negeri. ${ }^{46}$

e. Terdapat kode QR/Barcode

Di bagian tengah bawah kartu nikah, tepatnya di bawah foto pasangan suami istri terdapat barcode kecil yang jika dipindai akan keluar semua data pasangan suami istri, yaitu berupa nama pasangan, nomor buku nikah, nomor KTP, tempat dan waktu perkawinan.

f. Aman dan tidak mudah dipalsukan

Tidak seperti buku nikah, kartu nikah tidak mudah dipalsukan karena didesain dengan fitur kemanan yang baik, yang salah satunya dengan adanya barcode pada kartu nikah ini. ${ }^{47}$

g. Tidak mudah rusak

Dibanding dengan buku nikah, kartu nikah jauh lebih tahan dan tidak rusak karena bahan dasarnya yang berbeda. Buku nikah yang berbahan dasar kertas jika sering dibawa kemana-mana cenderung akan mudah sobek dan basah. Hal ini tentu tidak berlaku pada kartu nikah.

h. Bisa diganti jika rusak atau hilang tanpa dikenakan biaya

Pengurusan penggantian kartu nikah yang rusak atau hilang sangat mudah karena cukup dengan mendatangi dan melaporkan kerusakan/kehilangan tersebut ke Kantor Urusan Agama yang menerbitkan kartu nikah tanpa dipungut biaya karena berkaitan dengan akta kependudukan sebagaimana yang disampaikan oleh

\footnotetext{
45 Merdeka.com, "4 Kelebihan Kartu Nikah", dalam https://www.merdeka.com/peristiwa/4-kelebihan-kartu-nikah/mudah-dibawa-kemanapun-dan-kap anpun.html, diakses pada 28 Juni 2019.

46 Sindonews.com, "Ini Manfaat Kartu Nikah", dalam https://nasional.sindonews.com/read/1354764/15/ini-manfaat-kartu-nikah-1542212209, diakses pada 29 Juni 2019.

47 Liputan6, "Ini 4 Kelebihan Kartu Nikah", dalam https://www.liputan6.com/news/read/3691709/ini-4-kelebihan-kartu-nikah, diakses pada 28 Juni 2019.
} 


\section{Muhammadiyah Amin. ${ }^{48}$}

2. Kalangan yang menentang beralasan bahwa penerbitan nikah memiliki beberapa kelemahan sebagai berikut:

a. Tidak efektif dan efisien serta dikhawatirkan akan memboroskan anggaran negara

Beberapa kalangan anggota DPR menilai bahwa penerbitan kartu nikah bagi masyarakat belum mendesak untuk dilakukan karena praktik pencatatan di Kantor Urusan Agama dengan menggunakan buku nikah dinilai cukup baik. Selain itu juga, selama ini buku nikah telah cukup digunakan sebagai bukti adanya peristiwa pernikahan yang sah, baik menurut negara maupun agama. Beberapa di antara mereka bahkan menganggap bahwa kebijakan ini berpotensi memboroskan anggaran negara jika dicetat dalam jumlah banyak. Adapun jika tujuannya sebagai data kependudukan, sebenarnya data mengenai status perkawinan telah tercatat dalam E-KTP dan KK. ${ }^{49}$

Dalam hal ini, Kementerian Agama RI memastikan bahwa pengadaan kartu nikah bukan termasuk pemborosan dan penghamburan anggaran negara. Ada dua alasan yang disampaikan oleh Mohsen, yaitu:

1) Biaya percetakan kartu nikah pada tahun 2018 relatif murah karena hanya menghabisakan dana sebesar Rp. 680.000.000, untuk 1 juta kartu.

2) Nilai manfaat yang sangat jelas karena dapat digunakan untuk mengakses layanan online Kantor Urusan Agama di seluruh Indonesia, digunakan sebagai bukti perkawinan ketika pasangan suami istri hendak menginap di hotel syariah serta untuk memenuhi persyaratan layanan yang membutuhkan data tentang status perkawinan, misalnya layanan perbankan.

Pengadaan kartu nikah bukanlah merupakan progam dadakan dimana sudah melalui mekanisme persetujuan DPR sebelum pagu untuk anggaran 2018 ditetapkan. ${ }^{50}$ Selain itu, untuk selanjutnya Kementerian Agama telah merencanakan bahwa pengadaan kartu nikah tidak lagi menggunakan APBN murni, tetapi akan bersumber pada dana PNBP Nikah Rujuk di luar Kantor Urusan Agama. Kartu nikah ini penting untuk diterbitkan adanya ruang kosong kebutuhan

48 Siti Hadijah, "Kenali Apa Itu Kartu Nikah, Perbedaan dan Manfaatnya", dalam https://www.cermati.com/artikel/kenali-apa-itu-kartu-nikah-perbedaan-dan-manfaatnya, diakses pada 28 Juni 2019.

49 Hukumonline.com, "Penerbitan Kartu Nikah Menuai Kritik", dalam https://www.hukumonline.com/berita/baca/lt5bebf97509868/penerbitan-kartu-nikah-menuai-kritik/, diakses pada 29 Juni 2019.

${ }_{50}$ Hidayatullah.com, "Kemenag Jelaskan Fungsi Kartu Nikah"., dalam https:/www.hidayatullah.com/berita/nasional/read/2018/11/15/154872/kemenag-jelaskan-fungsi-ka rtu-nikah.html, diakses pada tanggal 29 Juni 2019. 
publik yang belum terpenuhi, sehingga kartu ini menjadi solusi sementara selama E-KTP masih dalam proses menuju single identity. ${ }^{51}$

b. Dikhawatirkan tidak sesuai dengan perencanaan dan dikorupsi

Pendapat ini muncul dari anggota KPK yang meminta untuk dilakukannya peninjauan ulang terhadap pengadaan kartu nikah sehingga karena alasan murah justru menjadi tidak efisien dan akhirnya hanya sebuah perubahan dari kertas menjadi plastik. Selain itu, dikhawatirkan juga terjadi korupsi pada proyek tersebut sebagaimana yang terjadi pada proyek pengadaan E-KTP. ${ }^{52}$ Dalam hal ini, Mohsen memastikan jika pengadaan kartu nikah dilakukan melalui tender terbuka dengan prosesnya yang transparan mekanisme yang berlaku dalam kerangka good governance. ${ }^{53}$ Bahkan Lukman Hakim Saifuddin mempersilahkan KPK untuk mengusut pengadaan kartu nikah, jika terdapat indikasi kuat adanya korupsi. ${ }^{54}$

c. Mudah hilang

Bentuknya yang sederhana dan praktis, setipis kartu ATM praktis menyebabkan kartu nikah mudah dibawa kemana-mana, sehingga sangat dikhawatirkan untuk mudah hilang. ${ }^{55}$ Adapun kemudahan penggantian kartu yang disampaikan oleh Muhammadiyah Amin di atas, rasanya telah cukup menghilangkan kekhawatiran terhadap tersebut. Apalagi faktanya kartu-kartu lain yang serupa bentuknya dengan kartu nikah, meskipun sering dibawa kemana-mana juga tidak dengan mudahnya hilang kecuali karena keteledoran atau sebab yang yang lain.

d. Sumber Daya Manusia yang belum siap

Tidak semua Kantor Urusan Agama memiliki tenaga ahli untuk mengoprasikan SIMKAH Web dalam rangka penerbitan kartu nikah. ${ }^{56}$ Dalam hal ini, Menteri Agama menyampaikan bahwa telah diadakan pelatihan fasilitator SIMKAH Web dengan mengundang perwakilan Kantor wilayah Kementerian Agama dari seluruh provinsi dan selanjutnya perwakilan tersebutlah nantinya akan memberikan pelatihan kepada seluruh operator Kantor Urusan Agama di wilayahnya sehingga mampu mengoperasikan SIMKAH Web

51 Sindonews.com, “Ini Manfaat Kartu Nikah".

52 Idntimes, "Polemik Kartu Nikah, Menteri Agama Lukman Hakim Kritik Balik KPK”, dalam https://www.idntimes.com/news/indonesia/helmi/polemik-kartu-nikah-menteri-agama-lukman-ha kim-kritik-balik-kpk/full, diakses pada 30 Juni 2019.

53 Hidayatullah.com, "Kemenag Jelaskan Fungsi Kartu Nikah".

${ }^{54}$ Idntimes, "Polemik Kartu Nikah, Menteri Agama Lukman Hakim Kritik Balik KPK".

55 Cekaja.com, "Mengenal Kartu Nikah yang Dikeluarkan oleh Kemenag", dalam https://www.cekaja.com/info/mengenal-kartu-nikah-yang-dikeluarkan-kemenag/, diakses pada 30 Juni 2019.

56 Pegawai Kantor Urusan Agama Kecamatan Wonocolo, Wawancara, Surabaya, 29 Juni 2019. 
tersebut. ${ }^{57}$

e. Infrastruktur yang belum memadai

Infrastruktur yang belum memadai tercermin dari sering koneksi jaringan dan trouble-nya server SIMKAH Web yang menghambat penyelesaian penerbitan kartu nikah. ${ }^{58}$ Disampaikan oleh salah satu pegawai Kantor Urusan Agama Kecamatan Wonocolo bahwa sejak menggunakan SIMKAH Web, proses pencatatan perkawinan satu pasangan yang biasanya hanya membutuhkan waktu 15 menit, baru dapat diselesaikan kurang lebih 1 jam. Hal ini karena SIMKAH Web hanya bisa diakses pada jam 8 sampai 12 siang, di atas jam tersebut sudah trouble, ditambah dengan koneksi jaringan yang tidak terlalu bagus. Selain itu, pencetakan akta nikah dan kutipannya (buku nikah) serta kartu nikah juga membutuhkan waktu yang lama karena menggunakan mesin printer khusus. ${ }^{59}$

Terkait dengan kesiapan teknologi informasi (TI) Kementerian Agama, Lukman Hakim Saifuddin menyatakan bahwa selama ini telah disediakan perangkat IT yang pengelolaannya secara sentral berada di bawah Biro Humas, Data dan Informasi Kemenag dengan Data Centernya berada di Jalan Lapangan Banteng dan di Gedung Kementerian Agama RI di Jalan MH Tamrin Jakarta. Kemampuan kapasitas server pusat sebagai pengelola database dan jaringan internet secara bertahap akan terus ditambah seiring dengan kebutuhan nasional. Adapun beberapa wilayah yang belum terjangkau jaringan internet, Direktorat Jendral Bimas Islam telah bekerjasama dengan Kementerian Informasi dan Komunikasi untuk membuka akses yang lebih luas agar seluruh Kantor Urusan Agama dapat terhubung dengan jaringan internet secara nasional sehingga dapat menyusul untuk dalam pengaplikasian SIMKAH Web dan kartu nikah. ${ }^{60}$

\section{Penerbitan Kartu Nikah di Era Digital Perspektif Maslahah}

Era digital adalah istilah yang digunakan untuk kemunculan digital, jaringan internet khususnya teknologi informasi komputer yang memiliki karekteristik dapat dimanipulasi, bersifat jaringan atau internet. Revolusi digital yang terjadi sejak tahun 1980 hingga sekarang telah mengubah cara pandang manusia dalam menghadapi kehidupan canggihnya pada saat ini. Sebuah teknologi dapat membuat perubahan besar terhadap seluruh dunia, dari mulai membantu dalam mempermudah segala urusan yang dimiliki sampai

57 Republika.co.id, "Kartu Nikah, Disorot tapi Dinanti”.

58 Keterangan Pegawai Kantor Urusan Agama Kecamatan Dukuhpakis (Holilurrahman (Pembimbing Praktik Kepenghuluan di KUA Kecamatan Dukuhpakis), Wawancara, Surabaya, 27 Juni 2019).

59 Pegawai Kantor Urusan Agama Kecamatan Wonocolo. Wawancara.

${ }^{60}$ Republika.co.id, "Kartu Nikah, Disorot tapi Dinanti". 
memunculkan masalah karena tidak dapat menggunakan fasilitas digital yang semakin lama semakin canggih dengan baik dan benar. ${ }^{61}$

Hal inilah yang menjadi salah satu latar belakang adanya inovasi dari Kementerian Agama RI berupa kartu nikah yang diluncurkan bersamaan dengan peluncuran aplikasi SIMKAH Web. Penerbitan kartu nikah juga dilatarbelakangi dengan maraknya pemalsuan buku nikah yang semakin lama semakin meresahkan masyarakat. Selain itu, penerbitan kartu nikah merupakan konsekuensi nyata dengan adanya perubahan terbaru terhadap Peraturan Menteri Agama Nomor 11 Tahun 2007 tentang Pencatatan Perkawinan menjadi Peraturan Menteri Agama Nomor 19 Tahun 2018 tentang Pencatatan Perkawinan, tepatnya yang tertuang dalam pasal 18 peraturan tersebut yang menyatakan bahwa pasangan suami istri akan memperoleh buku pencatatan perkawinan/buku nikah dan kartu perkawinan/kartu nikah dan setelah proses akad selesai dilaksanakan. Dengan demikian, keberadaan kartu nikah tidak menghapuskan buku nikah sebagai dokumen resmi namun sebagai pelengkap untuk memudahkan dalam menjalani kehidupan sehari-hari.

Sebagaimana yang dijelaskan sebelumnya, bahwa peluncuran kartu nikah telah menuai pro kontra dari berbagai kalangan yang tidak lain karena berbedanya pandanganmereka terhadap kelebihan dan kelemahan yang ada pada kartu nikah tersebut. Kalangan yang mendukung penerbitan kartu nikah ini tidak lain karena melihat banyaknya kelebihan yang dimiliki oleh kartu nikah ini, yaitu mudah dibawa kemanapun dan kapanpun karena bentuknya yang sederhana, tersambung dengan aplikasi SIMKAH Web sehingga mudah untuk mendapatkan data jika dibutuhkan, memudahkan akses layanan Kantor Urusan Agama di seluruh Indonesia yang sudah terkoneksi dengan aplikasi SIMKAH Web, dapat digunakan sebagai data dukung yang akurat karena terintegrasi juga dengan SIAK milik Kementerian Dalam Negeri, terdapat kode QR/Barcode sehingga aman dan tidak mudah dipalsukan, tidak mudah rusak karena bahannya kuat dan bisa diganti secara mudah dan gratis jika rusak atau hilang.

Adapun kalangan yang menentang adanya penerbitan kartu nikah memandang adanya beberapa kelemahan pada kartu nikah yaitu berupa dianggap tidak efektif dan efisien serta dikhawatirkan akan memboroskan anggaran negara dan tidak sesuai dengan perencanaan serta dikorupsi sebagaimana yang terjadi pada proyek pengadaan E-KTP, mudah hilang, ketidaksiapan SDM dan Infrastruktur. Jika dilihat dari pemaparan sebelumnya, terlihat jelas bahwa ketakutan dan kekhawatiran tersebut telah dimentahkan dengan adanya tanggapan dari pihak Kementerian Agama RI, yang menyatakan bahwa dana penerbitan kartu nikah relatif murah dan kedepannya tidak lagi menggunakan APBN namun dengan PNBP Nikah Rujuk di luar KUA, dilakukan dengan tender terbuka yang prosesnya transparan, kemudahan penggantian

\footnotetext{
61 Wikipedia: Ensiklopedi Bebas, "Revolusi Digital", dalam https://id.wikipedia.org/wiki/Revolusi_Digital, diakses pada 30 Juni 2019.
} 
kartu nikah ketika hilang atau rusak tanpa dipungut biaya, telah diadakannya pelatihan fasilitator SIMKAH Web untuk perwakilan dari seluruh Indonesia serta adanya perbaikan secara bertahap terhadap infrasuktur yang oleh Kementerian Agama bekerja sama dengan Kementerian Informasi dan Komunikasi. Meskipun begitu, perbaikan-perbaikan terhadap kekurangan yang ada dan muncul selanjutnya terkait pengoprasian SIMKAH Web dan penerbitan kartu nikah harus selalu dilakukan demi mewujudkan kemanfaatan yang lebih besar.

Dari analisis di atas, dapat disimpulkan bahwa penerbitan kartu nikah sebagai konsekuensi adanya peluncuran SIMKAH Web telah membawa dampak positif di era digital terutama dari segi efisiensi, orisinalitas dan integrasi data. Selain itu, kekhawatiran dan ketakutan dari kalangan yang menolak adanya penerbitan kartu nikah, khusunya yang berhubungan dengan pemborosan anggaran telah dimentahkan dengan beberapa argumentasi yang telah disebutkan. Dengan kata lain, penerbitan kartu nikah ini membawa kemaslahatan bagi manusia karena bersifat pasti dalam mewujudkan kemanfaatan dan menghindarkan kemadharatan, sejalan dengan syara' meskipun tidak dinyatakan secara eksplisit dalam nas, dan berlaku umum dengan berkaitan dengan kepentingan warga Indonesia, meskipun belum diterapkan di seluruh wilayahnya.

Jika dianalisis lebih lanjut menggunakan beberapa pembagian maslahah dapat dinyatakan bahwa:

1. Dari segi eksistensinya, penerbitan kartu nikah dapat dikatagorikan sebagai maslahah mursalah karena kemaslahatannya sama sekali tidak didukung atau ditolak oleh dalil syara', dalam arti tidak ada satu pun ayat al-quran dan hadis tetapi sejalan dengan hukum syara' yang bersumber dari al-qur'an dan hadis.

2. Dari segi tingkat kebutuhannya, masih sangat sulit untuk memutuskan penerbitan kartu nikah termasuk katagori maslahah hajiyah atau maslahah tahsiniyah. Oleh karena itu akan diulas lebih rinci dengan uraian berikut:

Penerbitan kartu nikah bukan termasuk rukun maupun syarat nikah yang disebutkan dalam Peraturan Menteri Agama Nomor 19 Tahun 2018 tentang Pencatatan Perkawinan dan peraturan-peraturan lain yang terbit sebelumnya, apalagi dalam figh munakahat pasti tidak ditemukan pembahasan mengenai kartu nikah. Sebagaimana yang telah disebutka sebelumnya, bahwa penerbitan kartu nikah ini dinilai sebagai pelengkap dari buku nikah karena diberikan bersamaan setelah proses akan nikah dilaksanakan. Oleh karena itu, untuk mengetahui kedudukan kartu nikah harus diketahui terlebih dahulu kedudukan buku nikah.

Kedudukan buku nikah secara implisit disebutkan dalam pasal 7 Kompilasi Hukum Islam yang menyatakan bahwa perkawinan hanya dapat dibuktikan dengan akta nikah yang dibuat oleh PPN, dan kutipannya/buku nikah yang memiliki kekuatan pembuktian yang sama akan diberikan kepada pasangan pengantin untuk disimpan dan digunakan ketika 
membutuhkan data terkait status perkawinan, tanpa buku nikah tersebut perkawinan tidak dapat dibuktikan bahkan dapat dinyatakan tidak pernah terjadi sehingga termasuk katagori maslahah daruriyah. Dengan demikian, penerbitan kartu nikah sebagai pelengkap buku nikah termasuk katagori maslahah hajiyah yang menyempurnakan keberadaan buku nikah dan memudahkan manusia dalam menjalani hidup dan menghilangkan kesulitan terutama yang berhubungan dengan pememelihara keturunan (hifdh al-nasl).

Selain itu, kurang tepat jika penerbitan kartu nikah ini hanya dikatagorikan sebagai maslahah tahsiniyah dalam arti dianggap hanya memberikan keindahan bagi kehidupan manusia, melihat faktanya bahwa keberadaan kartu nikah ini memberikan berbagai kemudahan untuk pemiliknya di era digital ini dalam pengurusan sesuatu yang memerlukan data terkait status perkawinan. Kartu nikah juga dapat mengatasi maraknya pemalsuan buku nikah yang biasanya berujung pada suatu perzinaan sehingga menyebabkan rusaknya keturunan, dalam arti pemeliharaan keturunan/hifdh al-nasl yang merupakan bagian dari kelima prinsip pokok dalam kehidupan manusia tidak dapat terjaga.

3. Dari segi kandungannya, penerbitan kartu nikah termasuk katagori maslahah 'ammah karena berkaitan dengan kepentingan orang banyak, dalam hal ini adalah warga Indonesia, meskipun belum diterapkan di seluruh wilayahnya, akan tetapi telah direncanakan secara bertahap bersamaan dengan perbaikan SDM dan infrastruktur yang dibutuhkan.

4. Dari segi perubahannya, penerbitan kartu nikah dapat dikatagorikan sebagai maslahah mutaghayirah karena merupakan kemaslahatan yang berubah-ubah sesuai dengan tempat dan waktu. Dalam hal ini, mungkin saja ketika suatu saat era digital berubah ke era yang baru, berubah pula kebutuhan manusia terkait dengan pembuktian keabsahan status perkawinan seseorang.

\section{Kesimpulan}

Pemberian kartu perkawinan atau yang dikenal dengan istilah kartu nikah di samping buku pencatatan perkawinan atau biasa disebut dengan istilah buku nikah untuk pasangan suami istri setelah proses akad nikah selesai dilaksanakan di depan Pegawai Pencatat Nikah adalah konsekuensi adanya Peraturan Menteri Agama Nomor 19 Tahun 2018 tentang Pencatatan Perkawinan yang merupakan perubahan terbaru atas Peraturan Menteri Agama Nomor 11 Tahun 2007 tentang Pencatatan Perkawinan. Pernerbitan kartu nikah ini telah menimbulkan polemik di kalangan masyarakat, terutama mengenai urgensi diterbitkannya kartu tersebut. Dalam hal ini, beberapa kalangan menilai bahwa penerbitan kartu nikah berdampak positif dalam menghadapi tuntutan di era digital sebagaimana sekarang terutama dari segi efisiensi, orisinalitas dan integrasi data; dan beberapa kalangan yang lain menyatakan bahwa penerbitan kartu nikah tidak diperlukan mengingat telah adanya buku nikah sehingga 
berpotensi memboroskan anggaran, namun pendapat ini telah dimentahkan adanya.

Jika dilihat dari segi eksistensinya, penerbitan kartu nikah dapat dikatagorikan sebagai maslahah mursalah karena sama sekali tidak didukung atau ditolak oleh dalil syara', tetapi sejalan dengan hukum syara' yang bersumber dari al-qur'an dan hadis; dari segi tingkat kebutuhannya, termasuk katagori maslahah hajiyah karena melengkapi keberadaan buku nikah dan memudahkan manusia dalam menjalani kehidupan dan menghilangkan kesulitan terutama yang berhubungan dengan pememelihara keturunan (hifdh al-nasl); dari segi kandungannya, termasuk katagori maslahah 'ammah karena berkaitan dengan kepentingan mayoritas warga Indonesia meskipun pelaksanaanya secara bertahap; dan dari segi perubahannya, dapat dikatagorikan sebagai maslahah mutaghayirah karena memungkinkan adanya perubahan kebutuhan manusia terkait dengan pembuktian status perkawinan sejalan dengan perubahan era.

\section{Daftar Pustaka}

Asmawi. "Konseptualisasi Teori Maslahah, dalam Salam: Jurnal Filsafat dan Budaya Hukum, 2014.

Cekaja.com. "Mengenal Kartu Nikah yang Dikeluarkan oleh Kemenag", dalam https://www.cekaja.com/info/mengenal-kartu-nikah-yang-dikeluarkan-ke menag/, diakses pada 30 Juni 2019.

Convensianews. "Kemenag Bakal Terbitkatkan Kartu Nikah, Begini Penampakannya", dalam https://covesia.com/news/baca/63643/kemenag-bakal-terbitkan-kartu-nika h-begini-penampakannya, diakses pada 29 Juni 2019.

Detiknews. "Begini Wujud Kartu Nikah Segera Gantikan Buku Nikah", dalam https://news.detik.com/berita/4296724/begini-wujud-kartu-nikah-yang-se gera-gantikan-buku-nikah, diakses pada 28 Juni 2019.

-----. "Kemenag Uji Coba Simkah Web di 2.000 KUA", dalam https://news.detik.com/berita/d-4303570/kemenag-uji-coba-simkah-web-d i-2000-kua, diakses pada 30 Juni 2019.

Faktualnews.co. "Pro Kontra Penerbitan Kartu Nikah", dalam https://faktualnews.co/2018/11/13/pro-kontra-penerbitan-kartu-nikah/107 958/, diakses pada 28 Juni 2019.

Hadijah, Siti. "Kenali Apa Itu Kartu Nikah, Perbedaan dan Manfaatnya”, dalam https://www.cermati.com/artikel/kenali-apa-itu-kartu-nikah-perbedaan-d an-manfaatnya, diakses pada 28 Juni 2019.

Harian Nasional. "Penerbitan Kartu Nikah Bertahap", dalam http://www.harnas.co/2018/11/12/penerbitan-kartu-nikah-bertahap, diakses pada 27 Juni 2019.

Hidayatullah.com. "Kemenag Jelaskan Fungsi Kartu Nikah", dalam https://www.hidayatullah.com/berita/nasional/read/2018/11/15/154872/ke menag-jelaskan-fungsi-kartu-nikah.html, diakses pada tanggal 29 Juni 
ADHKI: Journal of Islamic Family Law

2019.

Holilurrahman (Pembimbing Praktik Kepenghuluan di KUA Kecamatan Dukuhpakis). Wawancara. Surabaya, 27 Juni 2019.

Hukumonline.com, "Penerbitan Kartu Nikah Menuai Kritik", dalam https://www.hukumonline.com/berita/baca/lt5bebf97509868/penerbitan-k artu-nikah-menuai-kritik/, diakses pada 29 Juni 2019.

Idntimes. "Polemik Kartu Nikah, Menteri Agama Lukman Hakim Kritik Balik KPK",

dalam https://www.idntimes.com/news/indonesia/helmi/polemik-kartu-nikah-m enteri-agama-lukman-hakim-kritik-balik-kpk/full, diakses pada 30 Juni 2019.

K, Hamzah, "Urgensi Maslahah dalam Pembaharuan Hukum Islam di Era Global", dalam Al-Manahij: Jurnal Kajian Hukum Islam, Vol. 8, No. 2, 2014.

Kontan.co.id. "Ini Deretan Keunggulan Aplikasi SIMKAH Web yang dirilis Kemenag", dalam,https://nasional.kontan.co.id/news/ini-deretan-keunggulan-aplikas i-SIMKAH-web-yang-dirilis-kemnag diakses pada 30 Juni 2019.

-----. "Menag: Kartu Nikah Bukan Penghapus Buku Nikah", dalam https://nasional.kontan.co.id/news/menag-kartu-nikah-bukan-penghapusbuku-nikah, diakses pada 28 Juni 2019.

Kompas.com. "Kartu Nikah Diberikan Bersamaan dengan Buku Nikah, dalam "https://nasional.kompas.com/read/2018/11/12/21492291/kartu-nika h-diberikan-bersamaan-dengan-buku-nikah, diakses pada 29 Juni 2019.

Liputan6. “(Cek Fakta) Kementerian Agama Buat Kartu Nikah dengan 4 Kolom Istri", $\quad$ dalam https://www.liputan6.com/cek-fakta/read/3695757/cek-fakta-kementerianagama-buat-kartu-nikah-dengan-4-kolom-istri, diakses pada 29 Juni 2019.

-----. "Ini 4 Kelebihan Kartu Nikah", dalam https://www.liputan6.com/news/read/3691709/ini-4-kelebihan-kartu-nika h, diakses pada 28 Juni 2019.

Merdeka.com. "4 Kelebihan Kartu Nikah", dalam https://www.merdeka.com/peristiwa/4-kelebihan-kartu-nikah/mudah-dib awa-kemanapun-dan-kapanpun.html, diakses pada 28 Juni 2019.

Pasaribu, Muksana. "Maslahat dan Perkembangannya sebagai Dasar Penetapan Hukum Islam", dalam Jurnal Justitia, Vol. 1, No. 4, Desember, 2014.

Pegawai Kantor Urusan Agama Kecamatan Wonocolo. Wawancara. Surabaya, 29 Juni 2019.

Qusthoniah, "Al-Mashlahah dalam Pandangan Najmuddun al-Thufi", dalam Jurnal Syar'ah, Vol. II, No. II, Oktober, 2013.

Republika.co.id. "Kartu Nikah, Disorot tapi Dinanti", https://www.republika.co.id/berita/dunia-islam/islam-nusantara/18/12/31/ pk799p384-kartu-nikah-disorot-tapi-dinanti, diakses pada 27 Juni 2019.

"Mengapa Buku Nikah Diganti Kartu", dalam 
https:/www.republika.co.id/berita/nasional/news-analysis/18/11/12/pi1gl 3409-mengapa-buku-nikah-diganti-kartu, diakses pada 30 Juni 2019.

-----. "Penjelasan Kemenag Soal Penerbitan Kartu Nikah", dalam https://www.republika.co.id/berita/dunia-islam/islam-nusantara/18/11/12/ pi1dgz313-penjelasan-kemenag-soal-penerbitan-kartu-nikah, diakses pada 26 Juni 2019.

Rusdi, Muhammad Ali. "Maslahat sebagai Metode Ijtihad dan Tujuan Utama Hukum Islam", dalam Jurnal Syari'ah dan Hukum Diktum, Vol. 15, No. 2, Desember, 2017.

Syarifuddin, Amir. Hukum Perkawinan Islam di Indonesia; Antara Figh Munakahat dan Undang-undang Perkawinan. Jakarta: Kencana, 2009.

------. Ushul Fiqh. Jakarta: Kencana, 2011.

Tribunjakarta.com. "7 Hal tentang Kartu Nikah Diterbitkan secara Bertahap, Ini Kelebihannya", dalam https://jakarta.tribunnews.com/2018/11/14/7-hal-tentang-kartu-nikah-diter bitkan-secara-bertahap-ini-kelebihannya?page=3, diakses pada 29 Juni 2019.

Tribunnews.com, "Mudahkan Pencatatan Nikah, Kemenag Luncurkan Aplikasi SIMKAH", dalam http://www.tribunnews.com/nasional/2018/11/08/mudahkan-pencatatan-n ikah-kemenag-luncurkan-aplikasi-simkah, diakses pada 30 Juni 2019.

Wikipedia: Ensiklopedi Bebas. "Revolusi Digital", dalam https://id.wikipedia.org/wiki/Revolusi_Digital, diakses pada 30 Juni 2019.

Zuhdi, Muhammad Harfin. "Formulasi Teori Maslahah dalam Paradigma Pemikiran Hukum Islam Kontemporer", dalam Istinbat, Vol. 12, No. 1, Desember, 2013.

Kompilasi Hukum Islam.

Peraturan Pemerintah Nomor 9 Tahun 1975 tentang Pelaksanaan Undang-undang Nomor 1 Tahun 1974 tentang Perkawinan.

Peraturan Menteri Nomor 11 Tahun 2007 jo Peraturan Menteri Agama Nomor 19 Tahun 2018 tentang Pencatatan Perkawinan.

Undang-undang Nomor 1 Tahun 1974 tentang Perkawinan.

Undang-undang Nomor 22 Tahun 1946 jo Undang-undang Nomor 32 Tahun 1954 tentang Pencatatan Nikah, Talak dan Rujuk. 